\title{
RANCANG BANGUN MEKANISME PISAU PEMOTONG PADA MESIN PRESS DAN POTONG KANTONG PLASTIK UNTUK UKURAN PLASTIK 400 x 550 MM DENGAN KAPASITAS 500 POTONG/JAM
}

\author{
Muhamad Efendi \\ Fakultas Teknik, Program Studi Teknik Mesin \\ Universitas Muria Kudus \\ Email : Muhamadefendi7788@gmail.com \\ Masruki Kabib \\ Fakultas Teknik, Program Studi Teknik Mesin \\ Universitas Muria Kudus \\ Email: masruki.kabib@umk.ac.id \\ Rochmad Winarso \\ Fakultas Teknik, Program Studi Teknik Mesin \\ Universitas Muria Kudus \\ Email : rochmad.winarso@umk.ac.id
}

\begin{abstract}
ABSTRAK
Pada umumnya pisau pemotong kantong plastik masih menggunakan sistem dengan penggerak pneumatik maupun hidrolik tidak adanya inovasi baru untuk mengembangkanya. Tujuan dari penelitian ini yaitu merancang dan membuat pisau pemotong kantong plastik untuk ukuran plastik 400 x $550 \mathrm{~mm}$ serta mampu memotong plastik dengan kapasitas 500 potong/jam. Metode rancang bangun pisau pemotong kantong plastik meliputi proses perancangan sistem pemotong, gambar kerja, pembuatan. Pada tahap pembuatanya mencakup beberapa proses yaitu gambar kerja, pemotongaan bahan, pengelasan serta perakitan semua komponen dan uji coba untuk mengetahui hasil pembuatan mesin. Hasil penelitian ini didapatkan jenis pisau potong dengan kawat nikelin yang dialiri listrik arus $4 \mathrm{~A}$ dan menghasilkan panas serta mampu memotong kantong plastik dengan baik.
\end{abstract}

Kata kunci: Pisau Potong Kantong Plastik, Sistem Penggerak, Plastik

\begin{abstract}
ABSTRACK
In general, plastic bag cutting blades still use a system with pneumatic and hydraulic drives, there are no new innovations to develop. The purpose of this research is to design and make plastic bag cutting blades for $400 \times 550 \mathrm{~mm}$ plastic size and capable of cutting plastic with 500 pieces / hour. The method of designing a plastic bag cutting knife includes the process of designing a cutting system, working drawings, manufacturing. The manufacturing stage includes several processes, namely work drawings, material cutting, welding and assembling all components and testing to find out the results of making the machine. The results of this study obtained the type of cutting knife with wire nickel which is electrified current $4 A$ and produces heat and is able to cut the plastic bag properly.
\end{abstract}

Keywords: Plastic Bag Cutting Knife, Drive System, Plastic 


\section{PENDAHULUAN}

Plastik merupakan bahan yang sering digunakan dalam kehidupan manusia. Plastik juga dapat digunakan sebagai peralatan dalam kehidupan sehari - hari yang bersifat relatif kuat, ringan dan mempunyai harga yang murah. [ 1 ]

Mesin potong kantong plastik yang digunakan disebuah industri rumahan kelurahan sangkah surakarta menggunakan cara manual dalam sistem kerjanya. Kerja mesin seperti ini masih kurang efektif karena setiap menitnya hanya mampu memotong 15 lembar plastik dan semua itu tergantung pada tenaga operasionalnya. [11]

Sistem penggerak yang sering digunakan pada pisau pemotong kantong plastik ini terdiri dari berbagai jenis sitem penggerak yaitu seperti pneumatik, hidrolik, elektrik dan mekanik. Pada pisau pemotong sebelumnya menggunakan sistem penggerak pneumatik yang memudahkan bagi penggunanya untuk melakukan pekerjaanya. Penelitian Ini bertujuan untuk mengembangkan alat atau mesin tersebut pada sistem penggeraknya menjadi menggunakan sistem penggerak elektrik. [11]

Pada mesin press dan potong kantong plastik ini menggunakan aktuator elektrik jenis solenoid starter yang berarti alat yang digunakan untuk mengubah sinyal listrik atau arus listrik menjadi gerakan mekanis. Solenoid ini terbentuk dari suatu kumparan dengan inti besi yang dapat bergerak, besarnya tarikan dan dorongan yang dihasilkan ditentukan dengan jumlah dari lilitan kumparan tembaga dan besar arus yang mengalir melalui kumparan.

Plastik yang digunakan adalah plastik jenis PE, yaitu jenis plastik yang memiliki sifat dan karakteristik mudah dibentuk, memiliki nilai konstanta dielektrikal kecil yang membuat sifatnya baik terhadap kelistrikan, memiliki titik lebih rendah, fleksibel, dapat didaur ulang dan mudah untuk direnggangkan.

Mesin pengepress dan pemotong plastik memiliki berbagai jenis sistem penggerak maupun sistem kontrol yang digunakan. Misalnya saja di industri rumahan yang memiliki usaha tersebut masih menggunakan mesin press dan pemotong plastik manual atau masih menggunakan tenaga manusia. Mesin ini sebelumnya sudah dikembangkan oleh mahasiswa lain dengan menggunakan sistem penggerak pneumatik pada proses pemotongan plastik yang memudahkan penggunanya untuk melakukan pekerjaan. [ 11]

Sistem penggerak atau aktuator itu sendiri merupakan elemen yang berfungsi mengkonversi energi dari energi listrik ke energi mekanik. Aktuator berfungsi sebagai proses lanjutan dari keluaran suatu proses olah data yang dihasilkan oleh suatu sensor atau kontroller. [4 ]

Mesin pemotong plastik merupakan rancang bangun yang memiliki tujuan untuk memotong plastik supaya hasil pemotongan plastik tidak terlihat jelas dan hasil dari pemanasan plastik kurang terlihat karena kawat niklin kurang panas serta arus yang di keluarkan dari trafo sedikit kurang besar yang mengakibatkan putaran motor de satu dan dua kencang dan kawat niklin kurang panas. [10]

Pembuatan dan analisa yang memiliki fungsi untuk mencacah sampah yang memiliki jenis sampah botol plastik dengan spesifikasi dari mesin ini yaitu menggunakan motor daya $1.1 \mathrm{KW}$ dan putaran outputnya sebesar $2820 \mathrm{rpm}$ dan akan dihubungkan menggunakan transmisi sabuk $-\mathrm{V}$, yang mempunyai panjang keliling sabuk $1473 \mathrm{~mm}$, jarak sumbu poros $345 \mathrm{~mm}$ dan perbandingan diameter puli kecil dan besar sekitar $74.4 \mathrm{~mm}: 101.5 \mathrm{~mm}$. [ 6 ]

Kawat nikelin merupakan suatu kawat yang memiliki sifat tahan karat dalam keadaan murni. Nikel yang bersifat lembek tetapi apabila dipadukan dengan besi dan logam lain dapat membentuk baja tahan karat yang keras. Kawat nikelin dibagi menjadi dua macam yaitu nikel 200 dan nikel 201. [ 3 ]

Plastik memiliki berbagai macam jenis yang berbeda - beda yang digunakan sebagai bahan kemasan utama saat ini yaitu seperti polyethylene $(P E)$. Dan berdasarkan massa jenisnya Polyethylene dibagi menjadi dua jenis yaitu Low Density Polyethylene (LDPE) dan High Density Polyethylene (HDPE). [ 8 ] 
Proses permesinan merupakan proses yang terjadi pada suatu benda, yang berguna untuk merubah bentuk benda yang semula utuh menjadi benda yang bisa digunakan atau dimanfaatkan dengan cara pengukuran, pemotongan dan perakitan menjadi satu menggunakan alat bantu sebuah mesin. Pada proses pembuatan pisau potong kantong plastik ini terdiri dari berbagai tahapan dalam pengerjaanya yang menggunakan mesin seperti mesin bor, mesin potong, mesin las dan mesin grinda. [ 9 ]

Penelitian ini memiliki tujuan untuk mengembangkan mesin pemotong kantong plastik agar lebih bermanfaat kedepanya dan berguna meringankan beban masyarakat dalam menggunakanya. Tujuan lainya yaitu merancang dan membuat pisau pemotong kantong plastik untuk ukuran plastik $400 \times 550 \mathrm{~mm}$ serta mampu memotong plastik dengan kapasitas 500 potong/jam.

\section{METODOLOGI PENELITIAN}

Untuk melakukan perancangan serta pembuatan mesin potong kantong plastik ini, ada beberapa langkah - langkah yang harus dilakukan yaitu :

\subsection{Proses Perancangan Sistem Pemotong Kantong Plastik}

Perencanaan atau perancangan akan dilakukan terlebih dahulu sesuai dengan langkah langkah yang dilakukan.

Analisa kebutuhan pemotong plastik yang dilakukan dalam proses analisa kebutuhan meliputi aspek manufaktur, aspek produksi, aspek ergonomis, dan aspek keselamatan kerja.

Konsep desain sistem pemotong kantong plastik memiliki dua macam konsep yang akan dibandingkan untuk melihat perbedaanya antara konsep pertama dan konsep kedua yang memiliki kriteria berbeda - beda.

Perhitungan perencanaan sistem pemotong kantong plastik yang terdiri dari perhitungan pemotongan material, perhitungan kawat nikelin, batang pengarah, rangka dan perhitungan solenoid starter.

\subsection{Proses Pembuatan Sistem Pemotong Kantong Plastik}

Dalam proses manufaktur sistem pemotong kantong plastik harus memahami dan mempelajari proses kinerja mesin. Berikut adalah beberapa proses pembuatan yang dilakukan yaitu :

Pembuatan rangka sistem pemotong kantong plastik harus terlebih dahulu mempersiapkan alat dan bahan yang digunakan serta memahami gambar kerja yang digunakan. Beberapa langkah - langkah yang dilakukan dlam pembuatan yaitu pengukuran, menitik benda kerja, memotong, mengebor, dan mengelas.

Pembuatan tempat pisau potong memiliki beberapa hal yang harus dilakukan dalam pembuatan tempat pisau potong seperti harus memahami gambar kerja yang harus dilakukan, pengukuran, pemotongan, pengeboran dan proses pengelasan. Terakhir melakukan pengerjaan solenoid starter.

\section{HASIL DAN PEMBAHASAN}

\subsection{Pemilihan Konsep Desain}

Beberapa konsep desain sistem pemotong kantong plastik yang akan digunakan yaitu: 


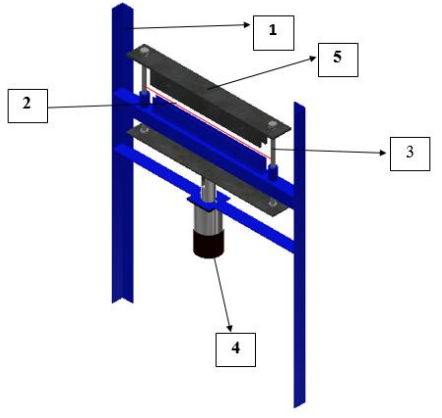

a.

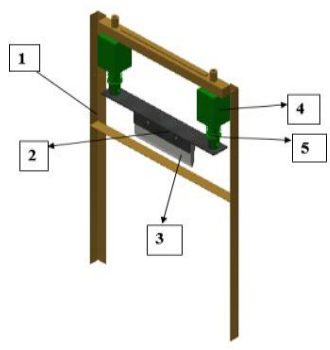

b.

Gambar 1. Konsep desain pertama (a) dan Konsep desain kedua(b)

Pada gambar 1 (a) konsep pertama komponen 1) rangka, 2) kawat nikelin, 3) alat bantu, 4) solenoid starter, 5) frame pisau potong. Pada gambar 1 (b) konsep kedua komponen 1) rangka, 2) frame pisau potong, 3) pisau potong, 4) dc solenoid elektromagnetik, 5) pegas.

Pemilihan konsep yang memenuhi syarat dan kriteria sistem pemotong kantong plastik adalah pada konsep yang pertama, dengan alasan desain sistem pemotong kantong plastik yang pertama lebih praktis dan juga tidak membutuhkan material atau komponen yang banyak. Kelebihan konsep konsep pertama dibandingakan dengan konsep kedua yaitu biaya pada proses pembuatan yang digunakan lebih murah dan mudah didapatkan dibandingkan dengan konsep kedua, hasil potongan lebih rapi dan baik konsep pertama dan perbedaan yang terlihat yaitu sistem kerja yang digunakan terlihat berbeda keduanya.

Mekanisme kerja dari sistem pemotong plastik ini yaitu memotong kantong plastik dengan daya motor stepper kapasitas 500 potong/jam dan solenoid stater akan mendapatkan aliran listrik atau sinyal on dari mikrokontroller dan kemudian akan terjadi arus listrik yang mengalir ke solenoid starter akan terjadi gerakan akibat induksi magnetik terhadap kumparan selenoid dan akan terjadi gerkan tarikan dan dorongan pada selenoid yang mengakibatkan kawat nikelin yang sudah dialiri oleh listrik sebelumnya bisa memotong kantong plastik, kantong plastik akan berjalan melewati pisau pemotong dan pisau pemotong akan otomatis memotong kantong plastik sesuai perintah serta terakhir dari proses pemotongan kantong plastik, hasil dari potongan akan terkumpul sampai 100 pcs dan akan digeser ketahap akhir setelah melewati proses pemotongan hasil dari pemotongan tersebut dapat memenuhi kapasitas 500 potong/jam.

\subsection{Perhitungan Perancangan Yang Digunakan}

Ada beberapa perhitungan yang terdapat pada perancangan mekanisme pisau potong kantong plastik yaitu :

Perhitungan pemotongan material yang akan dilakukan dapat berdasarkan persamaan 1:

$$
A=p \cdot t
$$

Perhitungan gaya pemotongan pada kantong plastik berdasarkan persamaan 2 :

$$
\begin{aligned}
& F=A . \sigma t \\
& F b=n \cdot F
\end{aligned}
$$

Perhitungan batang pengarah pada gambar 2 didapat dengan berdasarkan persamaan 3 : 


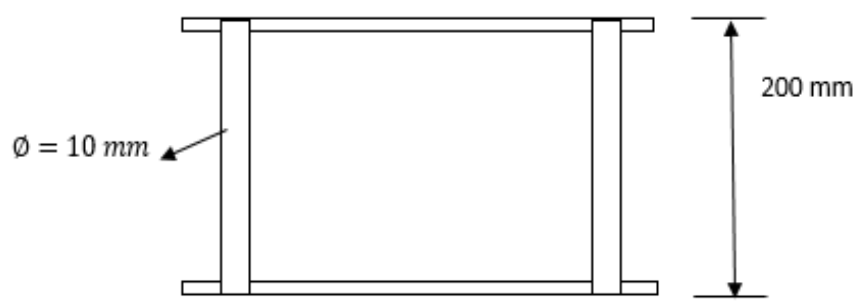

\section{Gambar 2. Batang pengarah}

$\mathrm{Vb}=\pi \cdot r 2 \cdot t$

$M b=\rho b \cdot V b$

Menentukan perhitungan yang terjadi pada selenoid starter berdasarkan persamaan 4:

Kekuatan tarik selenoid $=F+$ Mplunger

Dan gaya listrik dihitung berdasarkan persamaan 5, [5].

$f_{\theta}=2 \pi \cdot a \cdot N \cdot \beta \cdot i$

Hasil perhitungan pada perancangan sistem pemotong kantong plastik terdapat pada tabel 1 berikut ini :

Tabel 1.Hasil Perhitungan

\begin{tabular}{clcc}
\hline No & Perhitungan & Persamaan & Hasil \\
\hline 1 & Pemotongan material & $(1)$ & $16,5 \mathrm{~mm}$ \\
2 & Gaya pemotongan & $(2)$ & $371,25 \mathrm{~mm}$ \\
3 & Batang pengarah & $(3)$ & $0,12 \mathrm{~kg}$ \\
4 & Solenoid starter & $(4)$ & 20 \\
\hline
\end{tabular}

\subsection{Proses Pembuatan Sistem Pemotong Kantong Plastik}

Proses manufaktur sistem pemotong kantong plastik harus di ketahui terlebih dahulu memahami dan mempelajari proses kerja mesin dan bahan yang diproses.

\subsubsection{Pembuatan Rangka}

Bentuk rangka sebagaimana gambar 3. 


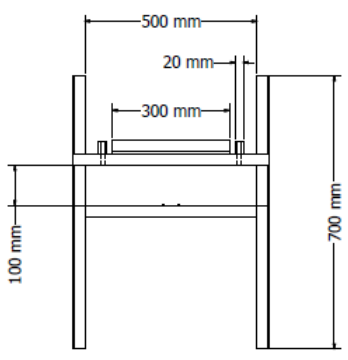

\section{Gambar 3. Desain Rangka}

Menghitung proses pengeboran pada frame sistem pemotong kantong plastik dengan berdasarkan persamaan 5:

Kecepatan $\operatorname{putar}(n)=\frac{n: 1000}{\pi \cdot d}$

Dalam menentukan proses perhitungan luas lasan berdasarkan persamaan 6 :

$A=a \cdot l$

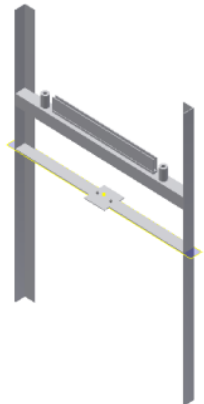

\section{Gambar .4. hasil pengelasan rangka}

Hasil pengelasan rangka ditunjukkan pada gambar 4. Hasil perhitungan yang didapat pada proses pembuatan rangka terdapat pada tabel 2 berikut :

Tabel 2. Hasil Perhitungan

\begin{tabular}{cccc}
\hline No & Perhitungan & Persamaan & Hasil \\
\hline 1 & Proses pengeboran & $(5)$ & $358,3 \mathrm{Rpm}$ \\
2 & Luas lasan & $(6)$ & $3200 \mathrm{~mm}^{2}$ \\
\hline
\end{tabular}




\subsubsection{Pembuatan Tempat Pisau Pemotong}

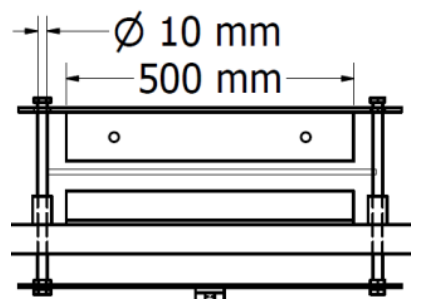

\section{Gambar 5. Desain Tempat Pisau Potong}

Proses pengeboran pada tempat pemotong kantong plastik bisa dihitung menggunakan persamaan 7 [ 9 ].

$n=\frac{v \cdot 1000}{\pi \cdot d}$

Perhitungan yang digunakan dalam proses pengelasan berdasarkan persamaan 8 [9] :

$A=a \cdot l$

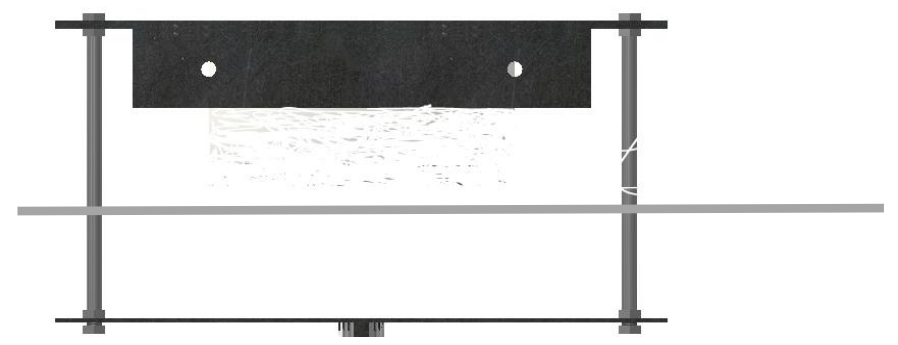

Gambar 6. Hasil pengelasan frame pisau potong

Hasil perhitungan yang didapat dari proses pembuatan sistem pemotong kantong plastik terdapat pada tabel 3 berikut ini :

Tabel 3. Hasil Perhitungan

\begin{tabular}{clcc}
\hline No & Perhitungan & Persamaan & Hasil \\
\hline 1 & Proses pengeboran & $(7)$ & $477,7 \mathrm{Rpm}$ \\
2 & Luas lasan & $(8)$ & $540 \mathrm{~mm}^{2}$ \\
\hline
\end{tabular}

\section{KESIMPULAN}

Hasil dari perancangan sistem pemotong kantong plastik ukuran 400 x $550 \mathrm{~mm}$ didapat data gaya pemotongan sebesar $371,25 \mathrm{~N}$, arus daya yang mengalir ke solenoida starter sebesar $20 \mathrm{~A}$ dan arus daya pada elemen pemanas kawat nikelin sebesar $4 \mathrm{~A}$.

Hasil pembuatan sistem pemotong kantong plastik ukuran 400 x $550 \mathrm{~mm}$ mampu memotong kantong plastik dan enggunakan kawat nikelin yang mudah menghantarkan arus listrik sebagai pemotong. 


\section{DAFTAR PUSTAKA}

[1]. Aripin, S. et al. (2017) 'Studi Pembuatan Bahan Alternatif Plastik Biodegradable Dari Pati Ubi Jalar Dengan Plasticizer Gliserol Dengan Metode Melt Intercalation', Teknik Mesin Universitas Bhayangkara Jakarta Raya Jakarta, 06, pp. 18-23.

[2]. Darmiati, I. E. (2017) 'Uji Jenis Kawat Penghantar Berdasarkan Deret Volta Menggunakan Kalorimeter', Program Studi Pendidikan Fisika Universitas Jember, 22-26

[3]. Hamzah, A. et al. (2016) 'Pengenalan Aktuator Pada Sistem Kendali Suhu Ruangan ( Aktuator Pendingin ) Berupa Kipas Angin Dc Dan Lampu Led Berbasis Mikrokonroler ( Arduino Uno ) Introduction Actuator Room Temperature Control System ( Actuator Air ) Dc Fan Form and Led Light Based M', Institut Pertanian Bogor, 1-9

[4]. Kabib, M. et al. (2016) 'Modelling And Simulation Analysis Of Solenoid Valve For Spring Constant Influence To Dynamic Response', ARPN Journal of Engineering and Applied Sciences Departemen of Mechanical Engineering, 11(4), pp. 2790-2793.

[5]. Kolontoko, I. S. (2012) 'ananlisa dan pembuatan mesin pencacah botol plastik (polietilena)', Jurusan Teknik Mesin, Universitas Gunadarma, 1-9

[6]. Munjahid (2017) 'Rancang Bangun Dies Mesin Pemotong Plat Hidraulis Untuk Gaya Pemotongan 432 KN', Teknik Mesin Universitas Muria Kudus, 1-7

[7]. Nindita, V. (2015) 'Studi berbagai metode pembuatan BBM dari sampah plastik jenis LDPE dan PVC dengan metode Thermal dan Catalytic Cracking (Ni-Cr / ZEOLIT)', Arsitektur Universitas PGRI Semarang, 10(3), pp. 137-144.

[8]. Rochim, T. (1993) proses pemesinan jakarta: erlangga.

[9]. Setyadjit, K. and Hariadi, B. (2016) 'Rancang Bangun Mesin Potong Plastik Rol Berbasis Mikrokontroller AT Mega 16', hasil penelitian LPPM, 01(02), pp. 169-178.

[10]. Wicaksono, A. R. (2015) mesin las dan potong kantong plastik berbasis pneumatik dengan mikrokontroller. salatiga. 